\title{
PENGARUH STRATEGI PEMBELAJARAN BEYOND CENTERS AND CIRCLETIME (BCCT) TERHADAP KREATIFITAS ANAK USIA DINI KELOMPOK USIA 3-4 TAHUN DI POS PAUD NUSA INDAH SURABAYA.
}

\author{
Rini Nur Kholifah ${ }^{1}$, Endah Hendarwati ${ }^{2}$, Aris Setiawan ${ }^{3}$. \\ Universitas Muhammadiyah Surabaya \\ Email : rinifriday@gmail.com ${ }^{1}$, endahhendarwati9@gmail.com ${ }^{2}$, \\ wedhangmusik@gmail ${ }^{3}$
}

\begin{abstract}
ABSTRAK
Permasalahan dalam penelitian ini adalah model pembelajaran klasikal yang digunakan guru dalam mengajarkan calistung kreativitas anak belum berkembang dengan optimal. Strategi pembelajaran beyond centers and circle time (bcct) dipilih sebagai suatu model pembelajaran yang berpusat pada anak. Dalam model pembelajaran tersebut terdapat suatu variasi prilaku kreatif yang digunakan untuk bahan penelitian. Rumusan masalah dalam penelitian ini adalah bagaimana aktivitas kreativitas anak usia dini dengan menggunakan pembelajaran beyond centers and circle time (bcct) dan pengaruh strategi pembelajaran beyond centers and circle time (bcct) terhadap kreativitas anak usia dini. Penelitian ini bertujuan untuk mengetahui bagaimana aktivitas kreativitas anak usia dini dengan menggunakan pembelajarn beyond centers and circle time (bcct) dan pengaruh strategi pembelajaran beyond centers and circle time (bcct) terhadap kreativitas anak usia dini. Jenis penelitian yang digunakan adalah penelitian kuantitatif dengan desain penelitian menggunakan Pre-Experimental Design dengan menggunakan Pre-Test-Post-Test Control Group Design. Populasi dari penelitian adalah anak Pos Paud Nusa Indah Surabaya. Kelompok B dengan jumlah anak 28, kelas eksperimen 14 anak dan kelas kontrol 14 anak. Teknik pengumpulan data dalam penelitian ini adalah dengan menggunakan observasi dan dokumentasi. Teknik analisis data adalah dengan menggunakan uji normalitas, uji homogenitas dan uji-t (t-test). Hasil penelitian menunjukkan bahwa kedua kelompok dinyatakan terdistribusi normal $(0,200>0,05)$ untuk kelompok eksperimen dan kelompok kontrol. Dari uji Homogenitas di dapat kedua kelompok bersifat homogen $(0.378>0,050)$ pada pretest dan $(0.554>0,05)$ pada hasil nilai dari kelompok eksperimen dan kelompok kontrol terdapat perbedaan mean sebesar 0,5 hal ini terlihat dari mean difference sebesar -0,5000. Hasil analisis Group Statistics Pretest dan Group Statistics Posttest terlihat ada perbedaan dengan ratarata pretest 6.143 berubah menjadi 9.714 dengan range kenaikan rata-rata 3.571. Sementara kelompok dengan pendekatan BCCT (Beyond Centers and Circle Time) mendapat hasil rata-rata 6.00 dan medapati kenaikan pada skor 10.214 dengan kenaikan skor sebesar 4.214. dengan demikian dapat di artikan bahwa penggunaan pendekatan BCCT (Beyond Centers and Circle Time) lebih efektif dalam meningkatkan kemampuan kreatifitas anak.
\end{abstract}

Kata kunci : Beyond Centers And CircleTime (BCCT), Kreativitas. 


\begin{abstract}
The problem in this study is the classical learning model used by teachers in learning calistung children's creativity has not been developed optimally. The learning strategy outside the center and the time circle (BCCT) was chosen as a child-centered learning model. The learning model requires a variation of creative behavior that is used for research material. The formulation of the problem in this research is early childhood creativity activities by using learning outside the center and the time circle (BCCT) and learning strategies outside the center and time circle (BCCT) towards early childhood creativity. This research aims to learn how to develop creativity outside the center and time circle (BCCT) and learning strategies outside the center and time circle (BCCT) towards the creativity of young children. This type of research is quantitative research with research design using Pre-Experimental Design using Pre-Test-Post-Test Control Group Design. The population of this research is the children of Pos Paud Nusa Indah Surabaya. Class B with 28 children, 14 experimental classes and 14 control classes for children. Data collection techniques in this study used observation and documentation. Data analysis techniques using the normality test, homogeneity test and t-test (t-test). The results showed that the second group was declared normally distributed $(0.200>0.05)$ for the experimental group and the control group. Homogeneity test in the second group can be homogeneous $(0.378>0.050)$ on the pretest and $(0.554>0.05)$ on the results of the value of the experimental group and the control group containing an average of 0.5 this can be seen from the mean difference of -0 , 5000. Analysis of Pretest Group Statistics and Posttest Group Statistics shows that there is a difference with the average pretest 6.143 changing to 9.714 with an average increase range of 3.571. While the group with the acquisition of BCCT (Beyond Center and Circle Time) got an average of 6.00 and found an increase of 10,214 with an increase in score of 4,214. BCCT (Beyond Center and Circle Time) is more effective in increasing children's creativity.
\end{abstract}

Key world : Beyond Centers And CircleTime (BCCT), Kreativitas.

\title{
PENDAHULUAN
}

Anak usia dini merupakan generasi penerus bangsa yang harus diperhatikan baik dalam aspek, pertumbuhan, perkembangan maupun masa depannya yang akan datang. Perkembangan anak yang baik akan membawa bangsa dan negara menjadi bangsa yang bermartabat dan akan melahirkan manusia-manusia yang berkualitas

Proses pendidikan pada anak usia dini hendaknya dilakukan dengan tujuan memberikan konsep yang bermakna bagi anak melalui pengalaman nyata. Hanya pengalaman nyatalah yang 
memungkinkan anak menunjukkkan aktifitas dan rasa ingin tahu secara optimal. Maka dari itu sangat penting menstimulasi perkembangan anak dengan pembelajaran yang penuh dengan kreatifitas, Kreativitas sangatlah penting dikembangkan sejak usia dini karena anak memiliki potensi besar untuk menjadi jembatan terpeliharanya kreativitas dalam diri manusia selanjutnya.

Pengembangan kreativitas pada anak dikelas dapat dilakukan dengan eksperimen pencampuran warna dalam kegiatan fingger painting dan menciprat warna pada gambar, bermain peran kemandirian anak dalam kegiatan memasang kancing baju dan berkolase, dan seni dalam kegiatan gerak mengikuti irama, serta bahasa dalam kegiatan menceritakan kembali buku cerita semut dan belalang. Dengan demikian diharapkan mampu memumbuhkan kreativitas anak yang optimal. Pada kenyataannya dikelas kreatifitas anak-anak sangat terbatas dan terkesan diabaikan, hal ini dikarenakan pembelajaran di Pos PAUD Nusa Indah masih menggunakan model pembelajaran klasikal. Klasikal ini tidak berfokus pada anak dan mengandalkan pembelajaran calistung saja. Oleh karenanya kreativitas anak sangat rendah dan pembelajaran sangat membosankan bagi anak-anak. Cara belajar anak-anak yang monoton ini sangat berpengaruh pada perkembangan kemampuan kreatifitas anak, imajinasi anak sangat terbatas sebab itulah model pembelajaran sentra sangat penting dipilih sebagai strategi yang sangat optimal untuk pengembangan kreativitas anak usia dini. Program pembelajaran berbasis Beyond Centers and Circle Time (BCCT) yang dilaksanakan melalui pendekatan sentra sesuai dengan minat anak. Beyond Centers and Circle Time $(B C C T)$ dipilih sebagai dasar pembelajaran yang akan diterapkan di Pos Paud Nusa Indah karena Beyond Centers and Circle Time (BCCT) mampu mengembangkan kreativitas anak yang lebih beragam.

\section{Dalam Beyond Centers and} Circle Time (BCCT) terdapat pijakan. Pijakan merupakan dukungan yang berubah-ubah disesuaikan dengan tahap pencapaian perkembangan anak dan bertujuan untuk mencapai tahap perkembangan yang lebih tinggi. Adapun 4 jenis pijakan tersebut adalah pijakan lingkungan main, pijakan pengalaman sebelum main, pijakan pengalaman saat main dan pijakan pengalaman setelah main. Pendekatan sentra yang digunakan dalam pembelajaran berbasis Beyond Centers and Circle Time (BCCT) dipilih peneliti karena pendekatan sentra merupakan model pembelajaran yang berpusat pada peserta didik. Kombinasi pembelajaran model sentra dan lingkaran dimana anak memilih sendiri kegiatan yang akan dimainkan. Kegiatan yang dipilih 
sesuai dengan minatnya sehingga kreatifitas anak dapat berkembang secara optimal. Dalam meningkatkan pelayanan pendidikan dimasyarakat Beyond Centersand Circle Time $(B C C T)$ banyak memberikan manfaat bagi lembaga Pos Paud Nusa Indah khususnya bagi peserta didik Pos Paud Nusa Indah. Hal ini terlihat dengan semakin bertambahnya murid dan aktif kehadiran anak-anak setiap harinya, anak-anak lebih fokus saat proses pembelajaran yang berlangsung dikelas, alokasi waktu pembelajaran lebih efisien sehingga stimulasi perkembangan lebih optimal.

Tujuan dari penelitian ini untuk mengetahui aktivitas kreativitas anak usia dini kelompok usia 3-4 tahun di Pos Paud Nusa Indah dengan menggunakan pembelajaran Beyond Centers and Circle Time (BCCT), mengetahui pengaruh strategi pembelajaran Beyond Centers and Circle Time (BCCT) terhadap kreativitas anak usia dini kelompok usia 3-4 tahun di Pos Paud Nusa Indah.

Strategi pembelajaran dapat diartikan sebagai kegiatan merencanakan pembelajaran yang berisi tentang rangkaian kegiatan yang harus dilakukan guru dan murid, termasuk di dalamnya penggunaan metode dan pemanfaatan sumber daya untuk mencapai tujuan pembelajaran yang efektif dan efisien.. Prinsip-prinsip pembelajaran pada anak usia dini haruslah sesuai dengan prinsip- prinsip pembelajaran bagi anak usia dini agar dalam menstimulasi perkembangan anak dapat optimal. model pembelajaran yang paling efektif bagi perkembangan anak usia dini adalah model pembelajaran berbasis sentra dan lingkaran. pendekatan sentra dan saat lingkaran adalah suatu pendekatan pembelajaran pada anak usia dini yang diselenggarakan dan berpusat pada sentra-sentra di dalam sebuah lingkaran dengan menggunakan 4 jenis pijakan. Pembelajaran model sentra memberikan kesempatan kepada anak untuk mengeksplorasi minat dan kemampuan yang ia miliki secara mandiri. Pembelajaran dengan pendekatan sentra merupakan pembelajaran student centre dimana pembelajaran berpusat pada anak, bukan pada pendidik. Pendekatan sentra dan saat lingkaran mempunyai prinsip bahwa kegiatan pembelajaran bertujuan untuk merangsang seluruh kecerdasan jamak yang dimiliki anak serta mendukung perkembangan kecerdasan tersebut, kegiatan pembelajaran berpusat pada anak, kegiatan belajar dilakukan melalui bermain dan setiap tahap perkembangananak melibatkan orang tua dan guru untuk mendukung kegiatan anak di rumah.Jenis pendekatan sentra yang digunakan antara lain yaitu sentra bahan alam dan sains, sentra balok, sentra seni, sentra bermain peran, sentra persiapan, sentra agama dan sentra seni tari gerak dan lagu. Perencanaan pembelajaran pendekatan sentra dan 
saat lingkaran meliputi beberapa tahap yaitu penataan lingkungan main, penyambutan peserta didik, main pembuka dan kegiatan transisi yang dilakukan dengan bernyanyi atau permainan sederhana. Evaluasi pembelajaran pendekatan sentra dan lingkaran merupakan suatu kegiatan penilaian melalui proses pengumpulan data yang digunakan untuk mengetahui tingkat kemajuan perkembangan anak saat anak melakukan kegiatan bermain, menggambar, menunjukkan hasil karyanya dan sebagainya. Penilaian yang digunakan sehari-hari dengan memberikan tugas kepada anak. Pencatatan penilaian berupa lembar penilaian perkembangan, catatan anekdot dan portofolio anak sedangkan penilaian yang digunakan dalam satu semester adalah buku rapot perkembangan anak.

Kreativitas dapat dikelompokkan menjadi dua, yaitu:

a. Kreativitas sebagai sebuah proseskreatif yakni sumbersumber kemampuan dan aktivitas seseorang yang berpotensi besar untuk melahirkan gagasan-gagasan baru. Dalam berpikir kreatif ini kreativitas ditekankan pada cara seseorang dalam memecahkan masalah dan menghasilkan sesuatu. Dalam hal ini perilaku atau aktifitas seseorang dalam memecahkan masalah atau menyelesaikan masalah dan menghasilkan sesuatu termasuk kedalam proses kreatif. b. Kreativitas sebagai hasil karya kreatif. Kreativitas diukur dari hasilnya bukan dari prosesnya. Sehingga sesorang melihat fenomena kreativitas sebagai sebuah hasil karya yang baru. Dalam hal ini potensi kreatif yang dimiliki seseorang belum tentu teraktualisasikan dalam bentuk perilaku yang dapat menghasilkan karya-karya baru yang berguna bagi lingkungan. Oleh karena itu, jika seseorang melihat fenomena kreativitas, maka lebih baik melalui karyakarya nyata yang telah dihasilkan seseorang daripada melihat bagaimana proses menghasilkan karya-karya tersebut.

Manfaat kreatifitas pada anak usia dini yaitu agar anak mampu mengemukakan ide dan gagasan baru, anak mampu menyelesaikan masalahnya dengan cepat dan tepat serta anak mampu menghasilkan karya baru yang semuanya itu dilakukan dengan cara bermain yang menyenangkan bagi anak. cara untuk mengembangkan kreativitas pada anak usia dini antara lain yaitu, dengan memberikan kesempatan dalam megemukakan ide atau gagasan baru, memecahkan masalah, dan menghasilkan karya baru melalui kegiatan eksperimen pencampuran warna, kemandirian membaca hadist pendek dengan 
kegiatan melipat, menghias bentuk rumah dan bunga serta mengikuti gerak dan lagu.

Hipotesis dari penelitian ini terdapat pengaruh positif antara strategi pembelajaran beyond centers and circle time terhadap kreatifitas anak usia dini dan aktifitas anak di pos Paud Nusa Indah Surabaya dengan hipotesis sebagai berikut:

1. H0 $(\operatorname{sig}>0,05)=$ di terima ada Pengaruh Strategi Pembelajaran Beyond Centers and Circle Time (BCCT) Terhadap Kreativitas Anak Usia Dini di Pos Paud Nusa Indah.

2. H0 (sig $<0,05)=$ di tolak / tidak ada Pengaruh Strategi Pembelajaran Beyond Centers and Circle Time (BCCT) Terhadap Kreativitas Anak Usia Dini di Pos Paud Nusa Indah.

Jenis penelitian yang digunakan adalah penelitian kuantitatif dengan desain penelitian menggunakan Pre-Experimental. Design dengan menggunakan PreTest-Post-Test Control Group Design. Dalam desain ini Kelompok Eksperimen maupun Kelompok Kontrol memiliki karakteristik yang sama atau homogen, karena diambil dari populasi yang homogen pula dan cara melakukannya satu kali pengukuran di depan (pre-test) sebelum adanya perlakuan (treatment) dan setelah itu dilakukan pengukuran lagi (post-test).

Instrumen penelitian digunakan untuk nilai variabel yang diteliti. Karena instrumen penelitian akan digunakan untuk melakukan pengukuran dengan tujuan menghasilkan data kuantitatif yang akurat, maka setiap instrumen harus mempunyai skala pengukuran. Pengukuran penelitian ini menggunakan check lis (daftar cocok) untuk mengukur proses kegiatan dalam sebuah pembelajaran melalui observasi.

Dalam penelitian ini pelaksanaan pretest dilakukan melalui observasi dengan mengamati selama kegiatan berlangsung. Hasil dari total poin nilai 84 dan rata-rata nilai pretest pada kelompok eksperimen 6,00 poin sedangkan pada kelompok kontrol total poin 86 dan nilai rata-rata $6,143 \quad$ poin kemudian nilai rata-rata pretest dari kedua kelompok tersebut digunakan untuk melakukan uji normalitas dan uji homogenitas data yang akan digunakan sebagai uji prasyarat analisis data 
Tabel 4.2

Hasil dari pretest kelompok eksperimen

\begin{tabular}{|l|c|c|c|c|}
\hline Nama & $\begin{array}{c}\text { Mengemuka } \\
\text { kan } \\
\text { ide dan } \\
\text { gagasan }\end{array}$ & $\begin{array}{c}\text { menyelesaikan } \\
\text { masalah dengan } \\
\text { cepat }\end{array}$ & $\begin{array}{c}\text { Menghasil } \\
\text { kan hasil } \\
\text { karya }\end{array}$ & $\begin{array}{c}\text { Total } \\
\text { poin }\end{array}$ \\
\hline Afrizal Rakasatya S. & 3 & 3 & 3 & 9 \\
\hline Ahmad Yazid Bustomi & 2 & 3 & 1 & 6 \\
\hline Ainul Istikomah & 1 & 1 & 1 & 3 \\
\hline Nadiatussholeha & 3 & 4 & 2 & 9 \\
\hline Amrizal Ibnu Mubarok & 2 & 1 & 2 & 5 \\
\hline Aqila Khanza Azzahra & 2 & 2 & 2 & 6 \\
\hline Azhar Al Abidzar & 2 & 2 & 1 & 5 \\
\hline Fitriyatus Zahro & 2 & 2 & 2 & 6 \\
\hline M. Farell Adlunafi & 3 & 1 & 2 & 6 \\
\hline Muhammad R. Al-Jailani & 1 & 1 & 1 & 3 \\
\hline Nadifa Aulia & 2 & 3 & 2 & 7 \\
\hline Nadine Azzahra D.K. & 1 & 2 & 1 & 4 \\
\hline Nadira Putri R. & 3 & 3 & 3 & 9 \\
\hline Salsabilla R. & 1 & 3 & 2 & 6 \\
\hline
\end{tabular}

Nilai total pretest 84

Tabel 4.3

Hasil dari pretest kelompok kontrol

\begin{tabular}{|l|c|c|c|c|}
\hline Nama & $\begin{array}{c}\text { Mengemukakan } \\
\text { ide dan gagasan }\end{array}$ & $\begin{array}{c}\text { menyelesaikan } \\
\text { masalah } \\
\text { dengan cepat }\end{array}$ & $\begin{array}{c}\text { Menghasilkan } \\
\text { hasil karya }\end{array}$ & $\begin{array}{c}\text { Total } \\
\text { poin }\end{array}$ \\
\hline Warirotun Ali & 2 & 2 & 2 & 6 \\
\hline Zavier Pandu Dewa P. & 3 & 2 & 2 & 7 \\
\hline Achmad Hazemul F & 3 & 2 & 3 & 8 \\
\hline Habib Mahdum & 2 & 3 & 2 & 8 \\
\hline Hidayatul Ilmiyah & 1 & 2 & 2 & 5 \\
\hline Najwatus Sifa & 2 & 1 & 2 & 5 \\
\hline Naura Layla S. & 1 & 1 & 1 & 3 \\
\hline M.Zhafran Novianto & 3 & 2 & 3 & 8 \\
\hline M.Zidan Alif & 2 & 2 & 2 & 6 \\
\hline Vinna Dwi. Octavia & 2 & 2 & 3 & 7 \\
\hline Aulia Rahmawati & 2 & 2 & 2 & 6 \\
\hline Marwah Nur R. & 1 & 2 & 2 & 5 \\
\hline Alya Nabila & 2 & 2 & 2 & 6 \\
\hline Jihan Safira & 2 & 2 & 2 & 6 \\
\hline
\end{tabular}

Nilai total pretest 86

Nilai total Posttest dari kedua kelompok tersebut kemudian digunakan untuk melakukan uji $\mathrm{t}(t$ test) untuk mengetahui tingkat signifikasi dari hasil perbedaan setelah perlakuan (treatment) dari kedua kelas tersebut 
PENGARUH STRATEGI PEMBELAJARAN BEYOND CENTERS AND CIRCLETIME (BCCT) TERHADAP KREATIFITAS ANAK USIA DINI KELOMPOK USIA 3-4 TAHUN DI POS PAUD NUSA INDAH SURABAYA.

Tabel 4.4 Hasil dari posttest kelompok Eksperimen

\begin{tabular}{|l|c|c|c|c|}
\hline \multicolumn{1}{|c|}{ Nama } & $\begin{array}{c}\text { Mengemukakan } \\
\text { ide dan gagasan }\end{array}$ & $\begin{array}{c}\text { menyelesaikan } \\
\text { masalah } \\
\text { dengan cepat }\end{array}$ & $\begin{array}{c}\text { Menghasilkan } \\
\text { hasil karya }\end{array}$ & $\begin{array}{c}\text { Total } \\
\text { poin }\end{array}$ \\
\hline Afrizal Rakasatya S. & 4 & 2 & 4 & 10 \\
\hline $\begin{array}{l}\text { Ahmad Yazid } \\
\text { Bustomi }\end{array}$ & 3 & 4 & 4 & 11 \\
\hline Ainul Istikomah & 4 & 4 & 4 & 12 \\
\hline Nadiatussholeha & 4 & 3 & 4 & 10 \\
\hline $\begin{array}{l}\text { Amrizal Ibnu } \\
\text { Mubarok }\end{array}$ & 3 & 2 & 3 & 8 \\
\hline $\begin{array}{l}\text { Aqila Khanza } \\
\text { Azzahra }\end{array}$ & 2 & 2 & 4 & 8 \\
\hline Azhar Al Abidzar & 3 & 2 & 4 & 9 \\
\hline Fitriyatus Zahro & 4 & 3 & 4 & 12 \\
\hline M. Farell Adlunafi & 4 & 3 & 4 & 11 \\
\hline $\begin{array}{l}\text { Muhammad R. Al- } \\
\text { Jailani }\end{array}$ & 3 & 3 & 3 & 9 \\
\hline Nadifa Aulia & 3 & 3 & 4 & 10 \\
\hline Nadine Azzahra D.K & 3 & 4 & 3 & 11 \\
\hline Nadira Putri R & 4 & 4 & 4 & 12 \\
\hline Salsabilla R & & 4 & 4 & 10 \\
\hline
\end{tabular}

Nilai total posttest 143

Tabel 4.5

Hasil dari posttest kelompok Kontrol

\begin{tabular}{|l|c|c|c|c|}
\hline Nama & $\begin{array}{c}\text { Mengemuka } \\
\text { kan } \\
\text { ide dan } \\
\text { gagasan }\end{array}$ & $\begin{array}{c}\text { menyelesaikan } \\
\text { masalah } \\
\text { dengan cepat }\end{array}$ & $\begin{array}{c}\text { Menghasilkan } \\
\text { hasil karya }\end{array}$ & $\begin{array}{c}\text { Total } \\
\text { poin }\end{array}$ \\
\hline Warirotun Ali & 4 & 4 & 4 & 12 \\
\hline Zavier Pandu Dewa P. & 2 & 3 & 4 & 9 \\
\hline Achmad Hazemul F & 3 & 3 & 2 & 8 \\
\hline Habib Mahdum & 4 & 4 & 4 & 12 \\
\hline Hidayatul Ilmiyah & 3 & 3 & 3 & 9 \\
\hline Najwatus Sifa & 4 & 2 & 4 & 10 \\
\hline Naura Layla S. & 3 & 3 & 3 & 9 \\
\hline M.Zhafran Novianto & 3 & 3 & 3 & 9 \\
\hline M.Zidan Alif & 3 & 4 & 3 & 10 \\
\hline Vinna Dwi. Octavia & 2 & 3 & 2 & 7 \\
\hline Aulia Rahmawati & 3 & 4 & 4 & 11 \\
\hline Marwah Nur R. & 3 & 3 & 2 & 8 \\
\hline
\end{tabular}




\begin{tabular}{|l|l|l|l|l|}
\hline Alya Nabila & 4 & 4 & 4 & 12 \\
\hline Jihan Safira & 2 & 4 & 4 & 10 \\
\hline
\end{tabular}

Nilai Total posttest 13

Uji normalitas dilakukan untuk mengetahui apakah data yang telah diperoleh di lapangan terdistribusi normal atau tidak. Sebab uji hipotesis baru bisa digunakan apabila data tersebut terdistribusi normal.Data yang diujikan yaitu data hasil dari rata-rata jumlah nilai pretest. Hasil dari perhitungan uji normalitas dengan menggunakan suatu sampel Kolmogorov-Smirnov dengan menggunakan taraf signifikasi KolmogorovSmirnov.Karena Uji: H0 ditolak apabila asymptotic signifikan value uji $<0,05$ dan H0 diterima apabila asymptotic signifikan value uji Kolmogorov > 0,05. 5\% $(\mathrm{p}=0,05)$ hasil terlampir dan diperoleh hipotesis:

$\mathrm{HO}=$ data sampel berasal dari populasi yang berdistribusi normal

$\mathrm{H} 1$ = data sampel berasal dari populasi yang tidak berdistribusi normal

Hasil dari uji normalitas yang dilakukan dengan menggunakan SPSS 16 menggunakan uji Kolmogorov-Smirnov pada tabel berikut:

Tabel 4.6

One-Sample Kolmogorov-Smirnov Test

Pretest

\begin{tabular}{|c|c|c|}
\hline Kelompok & Kontrol & Eksperimen \\
\hline Statistic & .214 & .183 \\
\hline Df & 14 & 14 \\
\hline Sig. & .081 & .200 \\
\hline
\end{tabular}

Postest

\begin{tabular}{|c|c|c|}
\hline Kelompok & Kontrol & Eksperimen \\
\hline Statistic & .173 & .152 \\
\hline Df & 14 & 14 \\
\hline Sig. & .200 & .200 \\
\hline
\end{tabular}

Kesimpulan:

Dari hasil tabel out put di atas dapat diketahui signifikasi sebesar 0.081 untuk kelompok kontrol dan 0.200 untuk kelompok eksperimen pada pretest. diketahui signifikasi sebesar 0.200 untuk kelompok eksperimen dan 0.200 untuk kelompok kontrol pada posttest. Karena nilai signifikasi lebih dari 0,05 maka dapat disimpulkan bahwa kedua kelompok data mempunyai varian yang sama atau dapat dikatakan kedua data terdistribusi normal. 
Tabel 4.9

Independent Samples Test

\begin{tabular}{|c|c|c|c|c|c|c|c|c|c|c|}
\hline \multirow{3}{*}{\multicolumn{2}{|c|}{ PRETEST }} & \multicolumn{2}{|c|}{$\begin{array}{l}\text { Lavene Test } \\
\text { for Equality } \\
\text { of Variances }\end{array}$} & \multicolumn{7}{|c|}{ t-test for Equality of Means } \\
\hline & & \multirow[b]{2}{*}{$\mathbf{F}$} & \multirow[b]{2}{*}{ Sig } & \multirow[b]{2}{*}{$\mathbf{t}$} & \multirow[b]{2}{*}{ df } & \multirow{2}{*}{$\begin{array}{l}\text { Sig. } \\
(2 \\
\text { tailed })\end{array}$} & \multirow[b]{2}{*}{$\begin{array}{l}\text { Mean } \\
\text { Differen } \\
\text { ce }\end{array}$} & \multirow[b]{2}{*}{$\begin{array}{c}\text { Std } \\
\text { Error } \\
\text { Differen } \\
\text { ce }\end{array}$} & \multicolumn{2}{|c|}{$\begin{array}{l}\text { 95\% Confidence } \\
\text { internal of The } \\
\text { Difference }\end{array}$} \\
\hline & & & & & & & & & Lower & Upper \\
\hline Nilai & $\begin{array}{l}\text { Equal } \\
\text { variances } \\
\text { assumed }\end{array}$ & .805 & .378 & -.219 & 26 & .829 & -.1429 & .6535 & -1.4861 & 1.2003 \\
\hline & $\begin{array}{l}\text { Equal } \\
\text { variances not } \\
\text { assumed }\end{array}$ & & & -.219 & 23.331 & .829 & -.1429 & .6535 & -1.4936 & 1.2079 \\
\hline
\end{tabular}

\begin{tabular}{|c|c|c|c|c|c|c|c|c|c|c|}
\hline \multirow{3}{*}{\multicolumn{2}{|c|}{ POSTTEST }} & \multicolumn{2}{|c|}{$\begin{array}{l}\text { Lavene Test } \\
\text { for Equality } \\
\text { of Variances }\end{array}$} & \multicolumn{7}{|c|}{ t-test for Equality of Means } \\
\hline & & \multirow[b]{2}{*}{ F } & \multirow[b]{2}{*}{ Sig } & \multirow[b]{2}{*}{$t$} & \multirow[b]{2}{*}{ df } & \multirow{2}{*}{$\begin{array}{l}\text { Sig. } \\
(2 \\
\text { tailed })\end{array}$} & \multirow[b]{2}{*}{$\begin{array}{l}\text { Mean } \\
\text { Differen } \\
\text { ce }\end{array}$} & \multirow[b]{2}{*}{$\begin{array}{c}\text { Std } \\
\text { Error } \\
\text { Differen } \\
\text { ce }\end{array}$} & \multicolumn{2}{|c|}{$\begin{array}{c}\text { 95\% Confidence } \\
\text { internal of The } \\
\text { Difference }\end{array}$} \\
\hline & & & & & & & & & Lower & Upper \\
\hline Nilai & $\begin{array}{l}\text { Equal } \\
\text { variances } \\
\text { assumed }\end{array}$ & .360 & .554 & .892 & 26 & 381 & -.5000 & .5607 & -1.6525 & .6525 \\
\hline & $\begin{array}{l}\text { Equal } \\
\text { variances not } \\
\text { assumed }\end{array}$ & & & .892 & 25.439 & .381 & -.5000 & .5607 & -1.6537 & .6537 \\
\hline
\end{tabular}

Hipotesis pada penelitian ini jika nilai signifikasi $>0,05$ maka $\mathrm{H} 0$ di terima dan jika nilai signifikasi $<0,05$ maka $\mathrm{H} 0$ di tolak dan $\mathrm{H} 1$ diterima. Pada tabel 4,9 Independent Samples Test pretest, terlihat nilai sig. 0.378 hal ini memperlihatkan bahwa terdapat perbedaan hasil penilaian belum secara signifikan antara kelompok eksperimen dan kelompok kontrol. Selanjutnya Pada tabel 4,9 Independent Samples Test posttest, terlihat nilai sig. 0.554 hal ini memperlihatkan bahwa terdapat perbedaan hasil penilaian antara kelompok eksperimen dan kelompok kontrol. pada hasil nilai dari kelompok eksperimen dan kelompok kontrol terdapat 
perbedaan mean sebesar 0,5 hal ini terlihat dari mean difference sebesar -0.5000 .

Hasil dari uji normalitas yang dilakukan dengan uji KolmogorovSmirnov menggunakan SPSS 16 diperoleh hasil signifikasi sebesar 0.081 untuk kelompok kontrol dan 0.200 untuk kelompok eksperimen pada pretest. Diketahui signifikasi sebesar 0.200 untuk kelompok eksperimen dan 0.200 untuk kelompok kontrol pada posttest. Karena nilai signifikasi lebih dari 0,05 maka dapat disimpulkan bahwa kedua kelompok data mempunyai varian yang sama atau dapat dikatakan kedua data terdistribusi normal.

Uji Homogenitas melalui lavene yang dilakukan dengan menggunakan SPSS 16 dapat diperoleh hasil signifikasi sebesar 0.378 pada pretest dan 0.554 pada posttest. Karena nilai signifikasi lebih dari 0,05 maka dapat disimpulkan bahwa kedua kelompok data mempunyai varian yang sama atau dapat dikatakan kedua data bersifat homogen. Maka apabila setelah diberikan perlakuan (treatment) pada kedua kelas terdapat perbedaan hasil antara kedua kelas. Hal ini bukan dikarenakan perbedaan kemampuan awal dari keduanya melainkan dari kedua kelas tersebut mendapatkan perlakuan (treatment) yang berbeda saat proses pembelajran.

Kemudian dilakukan uji t (t-test) untuk menguji hipotesis nihil (H0) yang mengatakan bahwa tidak ada pengaruh penerapan beyond centres and circle time (bcct) dengan yang tidak menerapkan beyond centres and circle time (bcct). Dengan Hipotesis statistik sebagai berikut:

$\mathrm{H} 0: \mu 1=\mu 2$ dan $\mathrm{H} 1: \mu 1>\mu 2$

Hipotesis :

$\mathrm{HO}=$ data sampel berasal dari populasi yang mempunyai variasi yang sama atau homogen $\mathrm{H} 1$ = data sampel berasal dari populasi yang mempunyai variasi yang tidak sama atau dikatakan tidak homogen.

Uji H0 apabila asymptotic signifikan value $<0,05$. Hipotesis pada penelitian ini jika nilai signifikasi $>0,05$ maka $\mathrm{H} 0$ di terima dan jika nilai signifikasi $<0,05$ maka H0 di tolak dan $\mathrm{H} 1$ diterima, Independent Samples Test pretest terlihat nilai sig. 0.378 hal ini memperlihatkan bahwa belum terdapat perbedaan hasil penilaian secara signifikan antara kelompok eksperimen dan kelompok kontrol sedang Independent Samples Test posttest, terlihat nilai sig. 0.554 
hal ini memperlihatkan juga bahwa terdapat perbedaan hasil penilaian secara signifikan antara kelompok eksperimen dan kelompok control. Rata-rata (mean) untuk kelompok eksperimen adalah 6.000 dan untuk kelompok kontrol adalah 6.143 dalam pretest dan dalam posttest kelompok eksperimen adalah 10.214 dan untuk kelompok kontrol adalah 9.714. Dapat diartikan bahwa rata-rata nilai posttest untuk kreatifitas dalam kelompok eksperimen lebih besar dari rata-rata nilai posttest kelompok kontrol. Berdasarkan hasil pengolahan data diperoleh data bahwa ratarata nilai posttest untuk kemampuan kreatifitas anak di Pos Paud Nusa Indah Surabaya pada kelompok eksperimen (kelas B1) lebih besar dari ratarata nilai posttest kelompok kontrol (kelas B2). Hal tersebut dapat diketahui dari hasil nilai rata-rata posttest kelompok eksperimen 10.214 sedangkan kelompok kontrol hasil nilai rata-rata posttest 9.714 terdapat perbedaan mean sebesar 0,5 hal ini terlihat dari mean difference sebesar -0.5000 .

Dalam penerapan beyond centres and circle time (bcct) memberikan pengaruh anak lebih fokus dalam menerima pembelajaran dikarenakan aktivitas anak sangatlah terfokus pada unjuk kerja dan hasil karya sebagai pemberian tugas dari guru yang kegiatannya sangat disenangi anak-anak. Sehingga dalam pembelajaran penerapan beyond centres and circle time (bcct) memberikan pengaruh efektif terhadap peningkatan kemampuan kreativitas anak. Guru memotivasi dan memberikan reward pada anak yang mampu berkreativitas dengan baik.

Aktivitas kreativitas anak usia dini di Pos Paud Nusa Indah dengan menggunakan strategi pembelajaran $B C C T$ (Beyond Centers and Circle Time), ada perbedaan signifikan antara aktivitas menggunakan pendekatan BCCT (Beyond Centers and Circle Time) dengan tanpa menggunakan BCCT (Beyond Centers and Circle Time). Aktivitas anak dalam mengemukakan ide dan gagasan baru, menyelesaikan masalah dengan cepat dan menghasilkan karya baru tanpa perlakuan BCCT (Beyond Centers and Circle Time) terlihat perbedaan yang signifikan dengan aktivitas anak dalam mengemukakan ide dan gagasan baru, menyelesaikan masalah dengan cepat dan menghasilkan karya baru dengan perlakuan $B C C T$ (Beyond Centers and Circle Time), hal ini terlihat dari hasil analisis uji t sig 0,378>0,554 
yang terdapat perbedaan mean sebesar 0,5 terlihat dari mean difference - 0,5000. Dengan demikian dapat di artikan bahwa penggunaan pendekatan $B C C T$ (Beyond Centers and Circle Time) lebih meningkatkan aktivitas kemampuan kreatifitas anak.

1. Ada pengaruh pendekatan BCCT (Beyond Centers and Circle Time) terhadap kreatifitas, yang berarti ada pengaruh kemampuan kreatifitas pada anak sebelum (pretest) dan sesudah (postest) diberikan pendekatan $B C C T$ (Beyond Centers and Circle Time). Berdasarkan pengaruh tersebut terlihat ada perbedaan yang signifikan antara kemampuan kreativitas menggunakan pendekatan BCCT (Beyond Centers and Circle Time) dengan kemampuan kreativitas tanpa menggunakan BCCT (Beyond Centers and Circle Time) dengan melihat hasil analisis Group Statistics Pretest dan Group Statistics Posttest terlihat ada perbedaan dari perbandingan hasil antara kelompok dengan BCCT (Beyond Centers and Circle Time) dengan kelompok tanpa pendekatan BCCT (Beyond Centers and Circle Time) Kelompok tanpa pendekatan BCCT (Beyond Centers and Circle Time) dengan rata-rata pretest 6.143 berubah menjadi 9.714 dengan range kenaikan rata-rata 3.571.Sementara kelompok dengan pendekatan BCCT (Beyond Centers and Circle Time) mendapat hasil rata-rata 6.00 dan medapati kenaikan pada skor 10.214 dengan kenaikan skor sebesar 4.214. dengan demikian dapat di artikan bahwa penggunaan pendekatan BCCT (Beyond Centers and Circle Time) lebih efektif dalam meningkatkan kemampuan kreatifitas anak.

Dengan demikian pendekataan melalui model strategi pembelajaran $B C C T$ (Beyond Centers and Circle Time) sangatlah efektif apabila diterapkan guna meningkatkan kemampuan kreativitas anak sehingga anak lebih fokus dalam perkembangan peningkatan kreatifitas kognitifnya. BCCT (Beyond Centers and Circle Time) merupakan model stategi pembelajaran yang tepat dan efisien dalam meningkatkan kemampuan kreativitas anak usia dini diharapkan agar tetap diterapkan supaya perkembangan kreativitas kognitif anak tumbuh dan berkembang secara optimal.

\section{DAFTAR PUSTAKA}

Sujiono, Yuliani. 2009. Konsep Dasar Pendidikan Anak Usia Dini. Jakarta: Indeks. 
Augusta, 2012. Pengertian Anak Usia Dini. Dari http://infoini.com/Pengertian Anak Usia Dini.

Aisyah Siti ,Dkk, 2010. Perkembangan Konsep Dasar Pengembangan Anak Usia Dini. Jakarta : Universitas Terbuka.

Kurniasih,Imas. S.Pdl, 2009. Pendidikan Anak Usia Dini. Edukasia.

Hariwijaya dan Sukaca. Bertiani, 2011. Paud Melejitkan Potensi Anak dengan Pendidikan Sejak Dini. Yogyakarta : Mahadhika Publishing.

Beichler dan Snowman, 2006. Perkembangan Anak. Bandung : PT.Remaja Rosdakarya.

Peraturan Menteri Pendidikan Nasional Republik Indonesia no 137. 2014. Standar Pendidikan Anak Usia Dini. Jakarta : Peraturan Menteri Pendidikan Nasional Republik Indonesia.

Poerdawarminta W, j,S, 1995, Kamus Umum Bahasa Indonesia. Jakarta : Balai Pustaka.

Kamus Besar Bahasa Indonesia, 2002, Depdikbud. Balai Pustaka, Jakarta: Balai Pustaka

Albrecht, K. Brain Power, 2005. Learn to Improve Your Thinking Skills, New York: Prentice, Inc. Englewood Cliffs.

Chofivah, S, 2008. Penerapan Metode BCCT di PAUD
Unggulan Nasional Anak Saleh Malang. Malang: Skripsi Fakultas Psikologi Universitas Islam Negeri Malang.

Asmawati, Luluk, 2014. Perencanaan Pembelajaran PAUD, Bandung: Remaja Rodaskarya.

Dariyo, A, 2004. Psikologi Perkembangan Anak Tiga Tahun Pertama. Bandung: apt. Refika Aditama,

Depdiknas DIY. Konsep Pendekatan BCCT (Beyond Centers and Circle Times). Bahan Seminar

Suyanto, 2005. Konsep Dasar Anak Usia Dini, Jakarta : Departemen Pendidikan Nasional.

Anita Yus, 2011. Model Pendidikan Anak Usia Dini, Jakarta : Kencana.

Santrok, J.W, 2008. Life Span Development Perkembangan Masa Hidup. Jakarta: Erlangga.

Suharnan,2005. Psikologi Kognotif, edisi Revisi, Surabaya : Srikandi.

Mayesty, Mary. Creative Activities for Young Children $4^{\text {th }} E d$ : Play, Development, and Creativity. New York: Delmar Publisher Inc., 1990.

Munandar, Utami, 1992. Mengembangkan Bakat Dan Kreatifitas Anak Sekolah: Petunjuk Bagi Orang Tua Dan Guru. Jakarta : Gramedia. 
Munandar, S.C. Utami,1988. Kreatifitas Sepanjang Masa,Jakarta : Pustaka Sinar Harapan.

Munandar, 1999. Kreatifitas, Kebudayaan, dan Perkembangan Iptek S.C.U., Kreatifitas dan Keberbakatan. Jakarta : Gramedia Pustaka Utama.

Nursisto, 2000. Kiat Menggali Kreatifitas, Yogyakarta : Mitra Gama Widya.

Supriadi, Dedi. 1994 Bandung : Alfabeta,

Mulyasa, H.E.Prof.Dr.M.Pd, 2012. Manajemen PAUD. Bandung: PT Remaja Rosdakarya.

Semiawan, Conny R, 2009. Kreativitas Keberbakatan : Mengapa, Apa, dan Bagaimana. Jakarta : PT Indeks

Sujiono, Yuliani, 2009. Konsep Dasar Pendidikan Anak Usia Dini. Jakarta Indeks.

Noor, Juliansyah, 2011. Metodologi Penelitian:
Skripsi, Tesis, Disertasi, dan Karya Ilmiah. Jakarta: Prenadamedia Group.

Sugiono,2008. Metode Penelitian Kuantitatif Kualitatif dan R\&D Bandung: Alfabeta

Anshori, Muslich dan Iswati, Sri 2009. Metodologi Penelitian Kuantitatif. Surabaya: Airlangga University Press.

Arikunto, Suharsimi.1990. Metode Penelitian. Jakarta: Angkasa Bahan Belajar

Sanjaya, W. 2007. Stategi Pembelajaran, Berorientasi Standar Proses Pendidikan. Jakarta : Media Group.

Suparman, Awi. 1997. Model Model Pembelajaran Interaktif. Bandung : Lembaga Administrasi Negara ( LAN ) RI.

Yarno, Drs,M.Pd,et.al 2017. Pedoman Penulisan Skripsi dan Artikel Surabaya: FKIP Universitas Muhammadiyah Surabaya. 